\title{
БЕЛЕШКЕ О СТВАРАЛАШТВУ (ПОКУШАЈ БОГОСЛОВСКОГ ИСТРАЖИВАҢА)
}

\author{
Недељко Ристановић* \\ Епархија Браничевска, Парохија смедеревска IX
}

Сажетак: Човек кроз разбијање постојећих форми има могућност да пориче датост, а не да се прилагођава. Да се датост превазилази самим материјалом који је лишен предметности и форме, бар када је сликарство и графика у питању, сведочи утисак које на посматрача несумьиво оставља ликовни израз, пружајући посматрачевом оку ново сагледавање стварности која представља печат „истински нове реалности». Међутим, ова реалност није случајност нити пасивност, какво примећујемо у Ренесанси, већ једно сагледавање стварности које нам потврђује јединство твари. Дакле стварност створеног има свој смисао која побуђује уметника на тражење познања, али ипак ово побуђивање иде даље чинећи искорак у правиу тежње за достигнућем која је виша од самог трагања и методологије.

Кључне речи: језик, знак, крај уметности, лепота света, преображај, линија, боја, истина

\section{Аутентично сведочанство}

Тешкоћа обликовања духовног искуства није у вези само са мањкавошћу људског језика и његовом ограниченошћу да изрази познање о Богу, већ и са тим да је стварност богословља често у супротности са чињеницом шта тај језик богословља објашњава или предаје. Из тих разлога прибегава се објашњавању уз помоћ логичких категорија, које по правилу одводе „метафизичком апсолуту”. Међутим, богословље није у објашњавању „научно изложених истина”, а још мање у убеђивању, већ првенствено у одговору, тачније у благовести. Богословље је слово о благој вести. Ово слово, тј. богословље сведочимо у нашим животима делатно, али и путем језика који је символички. Символички језик а не дискурсивни сведочи о стварности која извире из пуноће еклисиолошког

\footnotetext{
*ел.пошта: ned.ristanovic@gmail.com
} 
опита, а не језичких аналогија, која нас може одвести „претераној апофатици и неочишћеној катафатици”. Бог Син је „Оваплоћени Логос Оца” који нам даје ,реч коју је сам примио од Оца (Јн 17,8)". Кроз њега, а не кроз формалну логику ми откривамо да је његово постојање личносно. А то значи да је наше познање плод нашег сједињења са њим, кроз битисање, а нипошто нашег сједињења у самој суштини његовој, која је непричасна и несазнајна. Тачније, његова безграничност јесте својеврстан акт Божијег милосрђа, која нас чува од наше презасићености њиме, а у нашем сједињењу са њим разоткрива се она пуноћа живог искуства вечности, када наше речи престају да буду речи о стварности, већ речи које саме јесу стварност. Емпиријска стварност је таква да човек данашњице прибегава уопштавањима, пре него оживотворавању идеја или стваралачких потенцијала.

Али зар онда не треба да поставимо питање: Ако је објективна стварност таква да се сопствено одсуство сматра за садржај, зар не бисмо онда могли назвати ту стварност нестварношћу? Шта је узрок овом уопштавању?

За хришћане овај узрок може бити између осталог и у потискивању стваралачке интуиције. Али свако потискивање представља симптом који нам ништа не говори уколико се не иде ка разрешењу које се огледа у узроку, а не у последицама. Потискивање је одсуство подвига у историји, а то значи не само порицање историје, већ истине да се у емпиријском без подвига не може остварити над-емпиријско. Одричући се у историји „искре вечног живота” стваралац се не одриче стварања, бар не у формалном смислу, већ да ово изражавање кроз језик или знак на одстојању од стваралачког учешћа у животу. Тада уметниково присуство у стваралачком смислу сведочи више о његовом одсуству и продужетку тајне унижења. А губитком стваралачког сазнајног учешћа у животу, које се манифестује кроз човеков отклон од другог, он свој доживљај реалности још више релативизује и маргинализује, западајући у замку уопштавања. „Када се бавимо покушајем уопштавања, ми тада више не добијамо здружене карактеристике, већ апстрактне, уопштене и генеричке концепте у најстриктнијем смислу ре- 
чи." Зато, говорећи о стваралаштву, нама треба један „предлог” који ће се тумачити у смислу семантичке одређености, а то је преображени знак. Јер оно што је хипотеза у науци, то је за сликарство знак. ${ }^{2}$ Стваралачко сазнајно учешће у животу се не бави хипотезама, већ прогресивним сведочењем „од највишег ка реалном". То не значи да виђење у сликарству није утемељено на научним достигнућима. Неоимпресионизам није свар надахнућа или чуда, већ управо супротно, настаје на темељу развоја „научног експеримента”: „Истраживање неоимпресиониста полази од строго научног гледишта, али наука не обухвата читаву културу". ${ }^{3}$ То, опет, никако не значи да уметност осим свог научног погледа нема и ону „литерарну или поетску страну, окренуту ка трагању субјекта, и то се не може занемарити."4 Другим речима, има нешто што обухвата и науку и културу, а то је преображење, на основу којег и знак и језик задобијају своју пуноћу.

Свет је ступајући у јединство логоса постао материја, тј. сагласно светоотачкој мисли материја представља „чињенице енергије". Односно свет има логосни састав јер Логос кроз реч ипостазира материју у ,делатну чињеницу”. Исто као што и стваралац кроз свој логос посредством речи, или знака представља ,резултат и пројаву његовог логоса”. 5 Уметност користи речи или знак који се не ствара, већ се налази и стиче, тј. открива. Наиме, неопходна је еволуција знака у форму зато што је његов живот у форми, тј. слици. ${ }^{6}$ Према томе, знак је онда предзнак преображаја, јер постајући форма он проналази садржај у могућој слици преображеног света. Форма и знак,

${ }^{1}$ Георгије Флоровски, „Типови историјског тумачења”, у Теологија историје II (Сабрана дела Г. Флоровског, т. 17), прир. Благоје Пантелић и Златко Матић (Пожаревац: Одбор за просвету и културу Епархије пожаревачкобраничевске, 2016), 102.

${ }^{2}$ G. C. Argan. Studije o modernoj umetnosti (Beograd: Nolit, 1982), 141.

${ }^{3}$ Argan, Studije o modernoj umetnosti, 115.

${ }^{4}$ Ibid., 116.

${ }_{5}^{5}$ Христо Јанарас, Азбучник вере (Нови Сад: Беседа, 2000), 65.

${ }^{6}$ Miodrag B. Protić, Slika i smisao (Beograd: Nolit, 1960), 129. 
али и језик, морају уступити место аутентичном сведочанству, док је с друге стране семантичка пуноћа богословског језика садржана у богослужбеном животу Цркве. У првом случају имамо скривање које наговештава надвремену пуноћу, а у другом откривање ове пуноће. И скривање и откривање, међутим, нису два језика већ делатна чињеница човекове усмерености ка ипостасном остварењу путем стваралачког израза. Свет јесте створен, међутим, створени свет није довршен. Круна створеног света је човек који наставља даље стварање, а свет представља сведочанство о човековом стваралачком битију. Природа сведочи о Богу Творцу, али и о човеку као створеном творцу.

\section{Аскетска култура преображаја}

Хришћанство кроз откривање историје „открива историјска осећања", али и разоткрива и оправдава динамичку чињеницу човековог стваралаштва. Тачније, историја је област човековог стваралаштва и слободе. Међутим, историја је поље човековог живота, без кога је истинско стваралаштво незамисливо. Кроз самоодрицање коме је својствено саможртвовање, уметност постаје откривање човековог потенцијала, које постаје примарно, а то је „стварање себе” кроз превладавање света. Стога је стваралаштво „иманентно бићу”. Поред тога, откривање себе подразумева смелост. Тачније, спознају хришћанског циља, а то је преображење целокупне творевине. Односно преображење подразумева превазилажење историје, али и културе. ${ }^{7}$ Другим речима, превазилажење кроз преображење јесте одраз подвижничког живота.

Али, ,аскетска култура” не води неизоставно стваралаштву, јер аскеза јесте трагање које је амбивалентно. Стваралаштво зависи и од жеље за откривањем потенцијала онога што јесте сама бит стварања, а то је преображај. Плод преображаја није само експресија аскетског израза, већ и аскетска трезвеност:

\footnotetext{
${ }^{7}$ Георгије Флоровски, „Хришћанство и цивилизација”, у Теологија историје II (Сабрана дела Г. Флоровског, т. 17), прир. Благоје Пантелић и Златко Матић (Пожаревац: Одбор за просвету и кутуру Епархије пожаревачкобраничевске, 2016), 118.
} 
„Својство истинског стваралаштва није виртуозност разраде него аскетска трезвеност у самој разузданости стваралачких порива." П Подвижништво покајања је неодвојиво од хришћанства, али и од стваралаштва, те ова неодвојивост сведочи о томе да је аскетски подвиг средство, а не циљ. Средство је пројава наше слободе да изразимо наш живот „као пребивање у Богу", а не да злоупотребом слободе изразимо свој живот кроз теоретско уопштавање. Аскезом покајања ствара се нови човек који постаје способан за слободну стваралачку делатност стварања новог. Мада само стваралаштво ништа „није мање духовно него аскеза".

Овде је очигледна потврдна форма аскетизма, али због човекове склоности ка греху, ова форма често се преплиће са одречном формом, имајући у виду динамичку димензију слободе. Спознавање греха не као етичког већ егзистенцијалног промашаја, води покајању. У хришћанству је таква тврдња општеприхваћена, али није код сваког делатно потврђена. Наиме, иако потврђена, она неретко доспева само до признања грехова које суштински не доприноси нашем спасењу, јер како да се покаје неко ко не спозна да је то што чини последица раскинутог односа са Богом, ближњим и материјалном творевином?

Грех је отклон од католичанске истине, јер представља меру порицања и одстојања од стваралачке интуиције. Дакле, отклон од озарења оне светлости која представља извор словесног израза. За Софронија Сахарова озарење светлости, било очигледно или тајно, јесте оно што претходи спознаји греха. Тек тада наступа „почетак созерцања”. Посредством покајања „на човека нисходи благодат Светог Духа која га уводи у област божанског живота”, односно у област стваралачког прегнућа. Осећањем благодатног живота код човека се јавља једно стање благодарности и созерцавања твари као осмишљене очигледности. Тако потреба за преумљењем код Софронија постаје егзистенцијална чињеница порива за вечним животом.

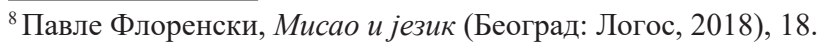


Међутим, порив за вечним животом овде и сада се не може сакрити, јер удови постају покретачи онога што је у срцу, а то је радост која одводи и упућује човека на другог. Ова упућеност на другог јесте истинска реална радост, које је данас, на несрећу, све мање. Али због чега? Свакако не због тога што људи не желе да се радују, већ можда више због тога што су свој живот утемељили на одбијању и отклону од учествовања са другим у Д(д)ругом, односно радости нестаје јер изостаје извор ове радости. Или, можда због тога што се радост схвата кроз „савладани страх” или преображену претњу, а не као динамичку чињеницу која је одраз преображеног живота.

Тема радости је најважнији садржај хришћанске дијалектике стваралачког живота. Ако радост можемо окарактерисати као темељно начело слободе, то онда значи да без радости нема слободе, односно онда имамо једно стање привидне слободе, јер се слобода не изражава као љубав, већ као равнодушност. Међутим, колико год стваралац био укорењен у овој радости, њега не може мимоићи бол процеса стварања. Човек као твоpeће биће не иде у правцу мимоилажења бола, већ у правцу дијалошке тишине. Тишина га учи суочавању првенствено са собом. Почетак и крај тог сагледавања јесте покајање. Покајање које би собом подразумевало признање није покајање, чак би се тешко могло назвати тачкастим привидом покајања. Покајање је поглавито трагалаштво дијалошке тишине под сводом небеским, трагалаштво ликујуће тишине која гута и прождире свераздирућу празнину. А празнина може бити дубока, како вели Е. Сиоран, али њена дубина је у томе што јој се крај не назире. Парадокс је у томе да је ова дубина релативна, јер се показује управо својим одрицањем од стварности, плитком, услед обесмишљавања реалности. Покајањем човек прави отклон од статичке перспективе где је лишен свог егзистенцијалног динамичког усмерења. Лишити се овог усмерења не значи још бекство у себе, нити чак когнитивно препуштање празнини, али већ само усмерење довољно говори о добровољном остајању у незамисливој и зјапећој празнини. А то је нешто што је поразно за хришћанина, као и за заједницу у целини, јер будући да смо сви чланови Тела Христовог, када 
страда један уд страда цело тело, тј. заједница. И ово страдање, не само спољашње, већ и оно унутрашње, многоипостасно је и као да наткриљује хришћанство током целе своје историје. Подвижништво је неодвојиво од уметности, јер подвиг омогућује да се „начело унутрашње лепоте природног материјала" подреди словесном упућивању човекове тварне природе догађају заједнице. С друге стране, можда ће се неко запитати због чега је пожељно уметничко дело посматрати из контекста заједнице? Иако аутори врхунских дела „нису имали намеру да изразе онтолошке космолошке и теолошке догмате и начела", она имају тежњу изласка из себе, ка другом, ка посматрачу, јер је оприсутњено утискивање овог стваралачког сазнања истине у њиховим радовима. Зато што је искуство истине за хришћане искуство заједнице, а не физичког преживљавања.

\section{Трансгредијентност уметничког дела}

Уметничко дело задржава способност духовног пробоја, јер оно, не схватајући се у оквиру временског или безвременог, у себи садржи важно својство „трансгредијентности”. 9 Из тих разлога уметничко дело постаје препознатљиво у свом допуштању различитог тумачења кроз сваку епоху. Осим једног, које не подлеже различитим тумачењима, јер се тиче искорака ка другом, који може бити стваралачки обликован, будући да порив и однос ка другом, произилази из стваралачке интуиције и созерцања истине.

Посматрајући историју уметничких прегнућа видимо да је античко уметничко дело безодносно, иако оно као такво није лишено стваралачког набоја. У њему не постоји релациона динамика између аутора и посматрача. Стиче се утисак да посматрач није потребан, јер је дело „потпуно у себи затворено”. Другим речима, суштинска слабост овог виђења јесте рефлексија самозатворености која порађа безгранично осећање покорности. Но, то не значи да ова дела нису уметничка. Напротив, она и данас плене својом лепотом, само се наше поимање

${ }_{9}^{9}$ Милан Узелац, Феноменологија нашег времена (Нови Сад: Сајнос, 2020), 81. 
уметности и људи античког времена разликује: „За све људе античке епохе уметност је била само моћ, техничко умеће у буквалном смислу те речи, способност преобликовања, уношење форме у неоформљен материјал, умеће којим се могло овладати, под строгим надзором вичних занатлија". ${ }^{10}$ Смисао у уметничким делима није нешто што она сама собом сажимају или успостављају, већ управо супротно, пожељно је да се смисао у уметничким делима доводи у питање. Али једно је доводити смисао у питање, а сасвим је друго негирати смисао, јер довођење смисла у питање, у уметничким делима указује на еманципацију од смисла, како би стваралачка дела својим естетским изразом направила отклон од апсурда.

Међутим, ова окренутост ка себи све је више присутна и у хришћанској цивилизацији. Аутаркична самозатвореност обгрљава човека и слаби његову стваралачку мисију у свету, те је неопходно тражење излаза. Уметничко дело није „догађај” као што је то за Шпенглера античко уметничко дело, нити је то „чин”, већ је то превасходно преображај, тј. израз преображеног света. Уметност кроз преображај настаје и истрајава као „нешто друго”, које не упућује толико на подражавање, бар не пасивно, колико на чињеницу да она у себи садржи могућност спознаје. Сходно томе, садржај уметности није у њеној пролазности, већ у непоновљивости. Али за Адорна пролазност уметности није у њеној хетерономности и зависности, већ у томе што она у себи носи заметак укидања, тј. самоукидања. ${ }^{11}$ Док сликарство од Леонарда на овамо прихвата посматрача, тако што он постаје ,увучен” у слику, у византијској култури имамо тенденцију релационе динамике којој су стране логичке предиспозиције, као што је то случај у натуралистичкој уметности. Ми овде не негирамо „стваралачку екстазу генија”, већ недопустивост , јеванђелске негације света", неимање смелости да се створени свет не уништи, већ превлада кроз преображај. Створени свет није створен да би био уништен, већ преображен, као што и у уметничком изразу он такође треба да

\footnotetext{
${ }^{10}$ Ibid., 278.

${ }^{11}$ Teodor Adorno, Estetička teorija (Beograd: Nolit, 1979), 30.
} 
буде потврђен кроз своју препознатљивост, да је преображен, а не уништен.

У јеванђелском прихватању света као дара, нема дакле увлачења посматрача које је у основи безодносно, већ излазак „из” и „ка” посматрачу. Дакле, имамо упућеност на другога, односно сусрет између посматрача и посматраног. То је дакле егзистенцијална динамика метафизичке интуиције, а не статика у којој самодовољност стреми високо. Однос уметничког дела према спољашњем је у прихватању овог споља, сублимирајући „емпиријски реалитет”, позивајући се на нову комуникацију. Уметничко дело не сме остати ствар, оно мора поседовати нешто више од стварствености, у којој се огледа његова посебност. Једно дело јесте предмет, али његова посебност је садржана у пројави истине која говори и прокламује преображај света. У овом преображају стоји њена саморазумљивост и комуникативност. Код Адорна комуникација дела је у његовој некомуникацији: „У односу на емпиријски реалитет, умјетничка дела подсјећају на теологуменон који је у часу откупљења био све оно што јест, а ипак и све потпуно друго."12 Динамика је у слободи, али она је на жалост летимична, стога је и замагљено откривање стваралачке природе човека. Ако је пут стваралаштва у откривању твореће природе човека из слободе, то онда значи да је човек метафизичком интуицијом усмерен на неуморно трагање и заснивање стваралачког живота овде и сада.

\section{Стваралачки интимизам}

Човеково стваралаштво треба да буде израз откривања динамичког интимизма, а овај динамички интимизам је логосна рефлексија излучевина словесног израза. За сликарство можемо рећи да је то уметност обликованог преображаја које настаје као плод егзистенцијалне стварности света. Динамика овог обликованог преображаја садржана је у у његовој појмљивости. Облик је сведок самотрансценденције, више него изражавање, стога је уметност неуморно „превладавање стварности и мењање света". Међутим, ово превладавање стварности омо-

${ }^{12}$ Ibid., 33. 
гућено је христоцентричном антропологијом, тј. правилном христологијом која нам открива истину о Богу и човеку, истину о човеку који има не само природно, већ слободно личносно битије. То не значи да можемо говорити о превасходству личности нити о превасходству природе, па самим тим ни о приоритету односа наспрам личности, већ о сапревасходству - јер није битно само оно споља, већ и оно унутра. Будући да искуство сваког од нас јесте пожељно и не може се занемарити, личност се дефинише у разликовању и особености, са спремношћу отвореног и вољног ступања у однос са другим, а никако у раздвајању од других. Стога разликовање и однос са другим доприносе кохерентнијем схватању појма личности.

Апсолутизација односа лако може одвести негацији светоотачког поимања личности, у најбољем случају релативизацији личности. Другост је индивидуа, појединац, а индивидуалност није исто што и индивидуализам. Личност и природу треба дакле разликовати, а никако раздвајати или супротстављати. Јер спасење и обоготворење човека садржано је у преображају природних својстава, а не њиховом укидању или уништењу. Индивидуални карактер не треба негирати већ преобразити. Није однос сам по себи превасходан, већ решеност да се кроз однос дође до личносног сусрета. Јер могуће је имати однос, а не доћи до остварења сусрета. Стога и јесте радост као темељ слободе, сусрет узајамног, а не наметнутог односа.

У апсолутизованој другости, други није предмет нашег посматрања, али ни интересовања, већ наметнутог односа. Антропологија је незамислива без исправне христологије. Лишавањем овакве антропологије афирмише се подела на профано и сакрално. Међутим, ,христолошка свест” је недовољно јасно исказана, те на историјску позорницу ступа хуманистичка антропологија, која је подређена нужности. Другим речима, хуманистичка антропологија, позитивизам и натурализам, само су рецидиви и последице неоткривене и пригушене антрополошке истине. Тачно је да је хуманизам имао хришћанске утицаје, али је био инспирисан духом класичне Грчке. Односно, овде на делу имамо отклон од стваралачке динамике човекове личности, јер је хуманистичка антропологија метафизичка 
еманципација која „не познаје човека као лик и подобије Божије, јер неће да зна Бога; не познаје човека као слободни дух, јер је он у власти природне нужности." Тако је вера превладана експанзијом модерног рационализма.

Али, зар бити личност не значи имати стваралачку интуицију и без уметничког дара? Иако је за уметност дар пожељан, човек самим чином стварања од Апсолутног Творца има у себи клицу стваралаштва која је словесно појмљива, и омогућује му да узраста у меру раста висине Христове. Зар није узрастање „У меру раста пуноће Христове” (Еф 4, 13) исто уметност, иако не у конвенционалном смислу, али засигурно у егзистенцијалном? Тако гледано сваки човек је стваралац, иако није сваки уметник, у смислу одређеног талента који је неопходан за неки уметнички израз. Односно није сваком дато да створи уметничко дело, али је сваком задато да узраста „у меру раста висине Христове.

\section{Стваралачка природа човековог достојанства}

Човеку није природно пребивати у аперсоналној деградирајућој позицији пасивизираног стања. Ту нема динамике. То је царство статичности, у коме је човек једино достојан да се диви Божијем величанству. У овој статичности остаје непомућена свест о сопственој ништавности, али у осећању ништавности не може бити речи о достојанству човека. Човек није ту само да би се дивио, већ и да би учествовао. Стога, реинтеграција човековог достојанства није садржана само у његовој стваралачкој природи, већ у наглашавању његовог синовства у Богу Оцу кроз Богочовека, благодаћу Духа Светог. Стваралаштво има своју Богочовечанску динамику, али изразито пневматолошког карактера, јер кроз „Усавршавајући Узрок” у слободи и слободом стваралачко постојање је обележено настављањем стварања Божијег света. Дух Свети нас уводи у једну стваралачку динамику служења, али не неким замишљеним вишим циљевима, нити служењу схваћеном као покорност, или потчињеност, већ у једно откривање човека као делатног бића које се састоји у његовом јединству са Христом. Црквено схватање служења је стога пневматолошко, јер Дух 
Свети јесте Онај Који нас ослобађа и онај који нам дарује слободу да уђемо у живот у коме нема окова смртности и пропадљивости, односно у живот који ће бити обележен подвигом стваралаштва.

Служење је у Богочовеку, јер тада служење постаје одраз моје љубави према творевини као одраз стваралачке енергије, која поприма облик динамичког сусрета са Христом. Стога хришћанима приличи да онај који је присутан као Бог Дух Свети јесте Онај Који их ослобађа од последица тварног и да нас једино Он може истински надахнути да мислимо, говоримо и једном речју стварамо. Бог рече и створи, а човек као тварно биће језиком оцртава преобликовање већ створеног од стране нествореног. Што не значи да се стваралац лишава стварања које можемо назвати уистину ново. Овде долазимо до значења појма створеног бића као са-ствараоца. Са-стваралаштво подразумева усвајање радости пре него логике. Стварање света од стране нествореног мора да је радостан чин, јер му је узрок у слободној вољи. Али и настављање стварања, од стране створеног бића требало би да буде радостан чин, јер је стварању узрок такође слобода.

Иако сам креативан чин уме и може бити тегобан и обележен чак неспокојством, јер је изражен „на известан начин", то не значи да изазива исти осећај и код посматрача. Као што не значи да ова тегоба стварања не може бити превладана код ствараоца његовом унутрашњом логиком. Али, то није истозначно са модерном рационалношћу, јер како стварати у свету, а истовремено имати логички однос према створеноме? Стварање подразумева логично нелогични однос, јер је љубав изнад оправдања и разумевања. Она је та која пројављује „славу Божију", а тиме и смирену љубав према свету и сваком створењу. Љубави је корелатив слобода, а слобода је „основна мелодија” стваралаштва, која је „изнад дужности и разумевања”. У супстанцијалности и тварности бића постоји клица или заметак егзистенцијалне стваралачке природе. Тварност твари у ствари је огледало стваралачке природе човека, јер да свет није тваран, како вели Берђајев, стваралаштво не би било могуће. Али исто тако, и човек да нема материјалну ипостас, ни спа- 
сење творевине не би било могуће, јер будући да човак има материјалну ипостас, за разлику од слободних бића које немају материјалну ипостас (попут анђела), он оправдава своје призвање, остварујући у себи јединство створеног са нествореним. Почетак овог јединства, или боље рећи облик овог јединства, назире се у стваралаштву. Свет је дакле створен слободном вољом Творца, а није еманација, тј. „излив Божанства”, већ потпуно слободан и ничим условљен стваралачки чин љубави, нестворене егзистенције. Еманација је порицање стваралачког чина Творца, али и стваралачког потенцијала створеног бића. За пантеистичко-еманативно поимање Бога не постоји стваралаштво, јер се човек умањује или прелива у божанство, али се стога афирмише теистичка концепција Бога која одводи у деизам. Еманација пориче слободу, а прокламује нужност. А у нужности нема стварања, већ прилагођавања датим формама. Ово имање је немање оног суштинског у уметности, а то је слобода, те стога, када се говори о прилагођавању, оно се не односи на стил или устројство мишљења, већ на пројаву слободе у стваралачкој уметности.

\section{Закључак}

Без враћања на темеље наше непоновљивости, који су садржани у чињеници стварања човека по образу и подобију, не може бити речи о истинском модернизму. Истинска авангарда није у трансавангарди, већ у осећању реалног јединства. Тачније, трансавангарди постаје својствена прожетост уметности и живота, као што је у раној авангарди карактеристично тесно „приближавање умјетности и живота”. ${ }^{13}$ Дакле, сликарство јесте пасивно, али, ово је активна пасивност која је усмерена на тачке које образују целину. Ако књигу хоћемо да доживимо као јединствену целину, ми то не можемо без повезивања кључних тачака. Сви покрети у сликарству, било рана авангарда или трансавангарда, јесу тачке које сабране чине целину.

Могућност постаје реализована само у својој недовршености, тако да се материјални свет кроз ове тачке сагледава као

${ }^{13}$ Ibid., 20. 
јединствен и непоновљив, будући да довршена култура почива на символу као алегорији, а не на реализму. Све што она собом представља јесте символ, а не истина тога што представља. Опет, недовршена култура није транскултурна већ инкултурна, јер улазак Богочовека у историју представља извориште културе и стваралаштва, те стога ова недовршеност потенцира слободу за, а не слободу од, односно слободу којом се стиже не до символа као алегорије, већ до символа као стварности. Другим речима, символички реализам постаје објективна реалност којом се помоћу словесног исказа постиже иманентност трансцендентног. Будући да недовршеност остаје отворена не за оно изнутра, већ за споља, на делу је стварање новог бића, новог живота. Али, Христос је трансцендентан у односу на културу и стваралаштво изнутра, омогућујући им на тај начин „пут ка трансцендентном”, пут ка Царству Божијем без кога су култура и стваралаштво непојмљиви.

\section{Литература:}

Adorno, Teodor. Estetička teorija. Beograd: Nolit, 1979.

Argan, C.G. Studije o modernoj umetnosti. Beograd: Nolit,1982.

Брдар, Милан. Филозофија у Дишановом писоару: постмодерни пресек $X X$-вековне филозофије. Нови Сад: Будућност, 2002.

Denegri, Ješa. „Pitanje originalnosti: ideal modernizma sumnja postmodernizma". Kriza originalnog $i$ savremena umetnost 139140, 3-4, 2008: 143-149.

Denegri, Ješa. „Teme moderne i postmoderne umjetnosti”. Y Pojmovnik suvremene umjetnosti. Ur. Miško Šuvaković, 19-25. Zagreb: Horetzky, 2005.

Mijušković, Slobodan. „Nema opasnosti”. Kriza originalnog $i$ savremena umetnost 139-140, 3-4, 2008: 177-190.

Protić, Miodrag. Slika i smisao. Beograd: Nolit, 1960.

Узелац, Милан. Феноменологија нашег времена. Нови Сад: Сајнос, 2020.

Uzelac, Milan. Estetika. Novi Sad: Stylos, 2003.

Флоровски, Георгије. „Типови историјског тумачења”. 
У Теологија историје II (Сабрана дела Г. Флоровског т. 17). Прир. Благоје Пантелић и Златко Матић, 73-106. Пожаревац: Епархија браничевска одбор за просвету и културу, 2016.

Флоровски, Георгије. „Хришћанство и цивилизација” у Теологија историје II (Сабрана дела Г. Флоровског, m. 17), прир. Благоје Пантелић и Златко Матић, 109-121. Пожаревац: Епархија браничевска одбор за просвету и културу, 2016.

Флоренски, Павле. Мисао и језик. Београд: Логос, 2018.

Belančić Milorad. Smrt slike, ogledi iz filozofije. Beograd: Krug, 2009.

Šuvaković, Miško. Epistemologija umetnosti ili O tome kako učiti učenje o umetnosti. Beograd: Orion Art, 2008. 
NOTES ON CREATIVITY (AN ATTEMPT AT THEOLOGICAL RESEARCH)

\author{
Nedeljko Ristanović \\ Diocese of Braničevo, Parish of Smederevo IX \\ e mail: ned.ristanovic@gmail.com
}

Summary: Nowadays, when it is characterized by making senseless and relativizing not only art. Already the entire metaphysical space, having in mind religion and philosophy, Hegel's warning and the annoucement of the end of art, today seem to have acquired a special meaning. In this paper, we tried to find models of affirmation and realization of a creative view of the world, including the poetic language of Christian theology, which in addition to representing the manifestation of existential peculiarity that is characteristic of transgressors in the field of artistic creation, can give us a cleaner insight, without which creation is unthinkable. The different forms of expression and their uniqueness are reflected in the fact that the artist should not subordinate his aesthetic impression to the logical structure of thought, but build them in such, a way that allows him to persevere in his uniqueness which reflects the uniqueness of the created person.

Keywords: language, sign, the place of art, the beauty of the world, transfiguration, line, color, true. 